his name and place of abode, and change of residence, if any, with the date of his diploma or letters 'testimonial, or in default thereof his name shall be omitted by the said Council from the next published copy of the said register; and a printed copy of the said registry for the time being so published by or under the direction of the said Council shall be evidence in all Courts, and before all Justices and others, that the persons therein specified are duly registered under this Act; and the absence of the name of any person from such printed copy shall be evidence, until the contrary be made to appear, that such person is not registered under this Act.

[To be continued in our next.]

\section{Fetentiral Fintellingetrer.}

\section{CHOLERA IN THE WEST INDIES.}

Dr. Hector Gavin has been despatched by the Colonial Office to Barbadoes, to assist in the application of preventive measures against the spread of cholera. A better selection of a medical officer could not have been made.

HAGYARD $v$. COATES.

On the 19th instant, in the County Court, Bridlington, Mr. Hagyard, Surgeon, of Hunmanby, brought an action against $J$. Coates, for 15s., for attendance in midwifery upon his wife. The detendant pleaded his inability to pay this amount. His Honour, Judge Raines, inquired the usual amount paid by the Board of Guardians in cases of midwifery ; and was informed that $10 \mathrm{~s} .6 \mathrm{~d}$. constituted the sum paid for confinements, without regard to distance, whcih induced his Honour to give a verdict of $10 \mathrm{~s} .6 \mathrm{~d}$. for the plaintiff. Although the plaintiff, a most respectable man, swore that Coates was able to pay the amount at once, the Judge directed him to pay $2 \mathrm{~s}$. a month; thus the profession will perceive that County Court law professes to regulate the charges of medical men by the "penny wise" folly of the Board of Guardians, and crowns the insult by the miserable and unnecessarily tedious manner in which the payments are made. It is high time that some legislative measure should be enacted to restrain the oppression which is daily victimising the honest practitioner from east, west, north, and south._Med. Times.

\section{PARISIAN MEDICAL SOCIETY.}

At the meeting of this Society, held on Friday evening last, the following gentlemen were elected officebearers for the next twelve-months:-J. W. Begbie, M.D., President; George Fleming, M.D., Vice. President; W. R. Sanders, M.D., Secretary; R. Sarell, Esq., Treasurer.

\section{ROYAL COLLEGE OF PHYSICIANS.}

At the quarterly meeting of the Comitia Majora, held on Monday, December 23rd, the following gentlemen, having undergone the necessary examinations for diploma, were admitted members of the College :Dr. Roberts, Brook Street; Dr. Rutherford Ancram, Valparaiso. The following gentlemen were admitted extra-licentiates:-Dr. Brett, Southampton Street Mornington Crescent; Dr. Sullivan, Chili; Dr. Alexander, North Audley Street.

\section{ROYAL COLLEGE OF SURGEONS.}

The Council have appointed Mr. Highley, the emi $\frac{\mathbb{}}{2}$ nent medical bookseller, of Fleet Street, to be thes publisher and bookseller to this College.

Gentlemen admitted Members on Friday, Decembet 13th, 1850 :-John Craven, York; James Char!esDickinson, London; Joseph Earle, Grosvenor Street: West; Edmund Lord Hudson, Bacup, Lancashire Johh Phillipson Langham, Forest of Dean, Gloucester Henry Maund, Bromsgrove, Worcestershire; Ashley Greenough, Northampton; Francis Henry Plumptre, Queen Square, Bloomsbury; Alex. Myall Robinson, Newbury, Berkshire; Robert Rygate, Colet Place, $\mathbb{D}$ Commercial Road; John Davis Weaver, Chester George Webster, Dulwich, Surrey.

Gentlemen admitted Members on Friday, December20th, 1850:-James Backhouse Bindloss; Thomas John Eames, Dorchester, Dorset; Alexander Carson, $\overrightarrow{\vec{\omega}}$ Colerain, co. Derry; John Gibson, Hackney ; Fred.W Hudson, Stock port, Cheshire; Nathaniel Walton Jones, Chichester, Sussex; Thomas John Jones, Amlwch, Anglesea; John Meane, Brighton, Sussex; Robert. Roberts, Dyffryn, Arduduy, Merionethshire; Robert Sproule, Brockagh, co. Donegal; Robert Wall, Cork.

\section{SOCIETY OF APOTHECARIES.}

Gentlemen admitted Thursday, Dec. 19, $1850:-\infty$ Alfred Beekitt, Thorne; Robert Bolton; John Gabriel French, Burton-on-Trent; James Jerwood, Hereford ; $\infty$ Robert Bohun Kidd, Norwich ; John Morton, Norfolk; Robert Rooke Piance, Adelande; William Sutherland; Nathaniel :Clement Wood, Norfolk; Nathaniel Stensong్ Wood.

\section{OBITUARY.}

In October last, at Peshawur, Dr. Lucas, assistat surgeon of the 61st Foot.

December 6th, at Dunsford, near Exeter, T. Froom, Esq., surgeon, aged 35.

December 13th, at Edinburgh, John Philip, Esq., $\overline{\mathrm{O}}$ assistant-surgeon, R.N., the only surviving son of John응 Philip, Esq., surgeon, of Kirkcaldy.

December 14th, at Portobello, Dr. John Squair, late $\vec{F}$ surgeon of the 8th Hussars.

December 24th, at Great Marlow, Bucks, William Hickman, Esq., in the 94th year of his age. The deceased was a pupil of the immortal Hunter, and had been in the active practice of his profession upwards of half a century; he died universally respected.

Lately, at Malvern, after a long and painful illness, in the 31st year of his age, T. S. Lee, Esq., formerly o of Gordon Place, Euston Square. Mr. Lee was well 3 known to the profession as the author of a work on "Uterine Tumours," which received a Jacksonian o prize of the College of Surgeons.

Lately, in Jamaica, of the epidemic cholera, Drs. Bailey, Murcott, Tabois, and Tait, and Mr. Fagden.

ERRATUM.-In the report of the cases admitted $\frac{7}{2}$ under Dr. Nelson, at the Queen's Hospital, Birmingham, inserted at page 707 of last volume, line 33 , for $\mathbf{N}$ the "greatest bore," read the "greatest bar" that can 으 present itself, \&c.

\section{TO CORRESPONDENTS}

Communications have been received from Mr. Stockwell, $\mathbb{\mathscr { D }}$ Dr. Robertson, Mr. Haggett, and Mr. Banks.

It is requested that all letters and communications $T$ connected with the Editorial department be sent to J. H. Walsh, Esq., Foregate Street, Worcester. Parcels and books for review may be addressed to $\vec{D}$ the care of Mr. Charchill, Princes Street, Soho. \title{
.
}

